Heart of Oak

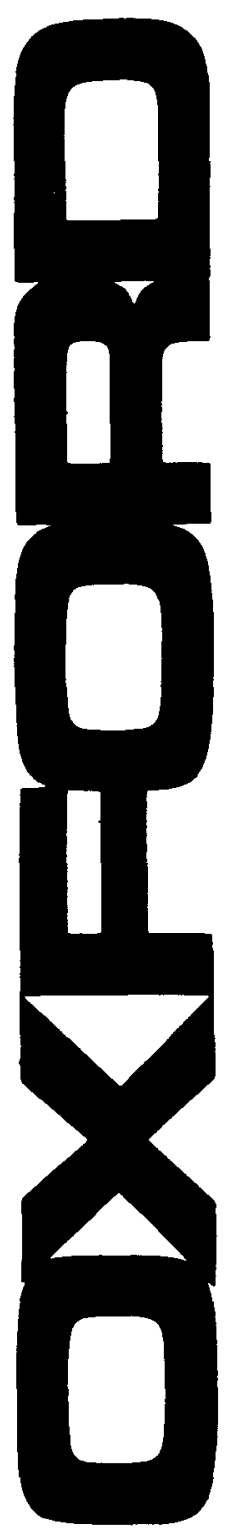

A Survey of British Sea Power in the Georgian Era GEOFFREY J. MARCUS. The Georgian era was the greatest in the history of the sailing Navy of Britain. This study covers various aspects of the navy's strength from the reigns of George I to George IV.

$1975 \quad 320$ pp.; 60 illus.; 5 charts

$\$ 27.50$

From the Dardanelles to Oran

Studies of the Royal Navy at War and Peace 1915-1940

ARTHUR J. MARDER, University of California, Irvine. Professor Marder continues his research on the Royal Navy in five essays dealing with controversial subjects during and after the first World War. He reconsiders the naval aspects of the Dardanelles and whether the Royal Navy adequately learned the lessons of war. $1974 \quad 320$ pp.; 15 illus.; 5 maps $\$ 21.00$

\title{
A History of the Oxford University Press
} Volume I, To the Year 1780

HARRY CARTER. This is the first volume of a two- or possibly three-volume series which will deal comprehensively and in detail for the first time with the history of the University Press from its origin up to the present. This book provides a unique contribution to the history of publishing and printing.

$1975 \quad 672$ pp.; 73 illus. $\$ 48.00$

The House of Lords and the Labour Government 1964-1970

JANET P. MORGAN. This book offers a descriptive analysis of the overwhelmingly conservative House of Lords during the years of Labour government between 1964 and 1970 . The author examines the deliberative and legislative role of Lords in a period of constitutional change.
1975
$270 \mathrm{pp}$.
$\$ 25.75$

The Compact Edition of the Dictionary of National Biography

The Complete Text Reproduced Micrographically 19753,000 pp. in two vols., cased $\$ 125.00$ the set

A Bibliography of British History to 1485 Based on The Sources and Literature of English History from the earliest times to about 1485 Edited by EDGAR B. GRAVES $1975958 \mathrm{pp}$. in two vols. prob. $\$ 81.00$ Prices are subject to change. 


\section{ESSAYS ON JOHN MAYNARD KEYNES \\ MILO KEYNES, Editor}

"All admirers and disciples of Keynes, and many more, will be grateful to the great man's nephew for having undertaken and so successfully accomplished the task of presenting the whole man behind the work." - The Guardian

$\$ 16.50$

\section{JANE AUSTEN}

\section{Bicentenary Essays}

JOHN HALPERIN, Editor

Nineteen original essays reflecting the current critical attitudes of the twentieth century's most influential Austen scholars, among them Mary Lascelles, A. W. Litz, Marvin Mudrick, Reuben Brower, Barbara Hardy, Jane Aiken Hodge and Robert Heilman.

Cloth $\$ 16.95 \quad$ Paper $\$ 5.95$

\section{IN OUR INFANCY}

An Autobiography: 1882-1912

HELEN CORKE

The fascinating story of Helen Corke's early years, including the D. H. Lawrence letters to Helen, the full text of the Freshwater Diary and letters from Jessie Chambers (Miriam in Sons and Lovers).

\section{THE CORRESPONDENCE OF}

\section{LORD ACTON AND RICHARD SIMPSON}

\section{Volume 3}

JOSEF L. ALTHOLZ, DAMIAN McELRATH and

JAMES C. HOLLAND, Editors

This volume, covering the period from July 1862 to Simpson's death, completes the correspondence.

$\$ 39.50$

\section{ANGLO-SAXON ENGLAND}

\section{Volume 4}

PETER CLEMOES, Editor

Among the many topics in this volume are pre-Conquest music, royal genealogies, interpretations of Old English poetry, metal work, and Viking settlements. 


\section{THE ANCIENT STATE}

\section{Authoritie and Proceedings of the Court of Requests by Sir Julius Caesar \\ L. M. HILL, Editor}

The judicial world as observed by Sir Julius, Judge of the High Court of Admiralty, Master of Requests, Chancellor of the Exchequer, Master of the Rolls and Privy Councillor. $\$ 25.00$

\section{THE REPRESENTATIVE OF THE PEOPLE? \\ Votes and Voting in England Under the Early Stuarts DEREK HIRST}

An assessment of the extent to which there was a representative democracy in England before the Civil War. Dr. Hirst demonstrates that the House of Commons did indeed represent the common people, both numerically and by responding to their grievances. $\$ 21.00$

\section{A MACHIAVELLIAN TREATISE BY STEPHEN GARDINER}

PETER S. DONALDSON, Editor and Translator

In this work, Gardiner analyzes the dynastic changes in England's past in order to provide Philip II with a guide to ruling England and establishing a Catholic dynasty.

$\$ 19.50$

\section{BRITAIN AND EAST ASIA 1933 to 1937 ANN TROTTER}

An important study drawing upon the Foreign Office archives and the Leith Ross papers.

$\$ 23.50$

\section{THE IMPACT OF HITLER}

\section{British Politics and British Policy 1933-1940}

\section{MAURICE COWLING}

The author describes in detail the relationship between British party politics and the conduct of British foreign policy from Hitler's arrival in office to Chamberlain's resignation.

\section{Cambridge University Press}

32 East 57th Street, New York, N. Y. 10022

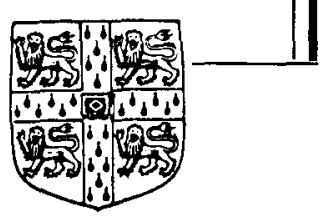




\section{EIRE-IRELAND}

\section{A QUARTERLY JOURNAL OF IRISH STUDIES}

\section{Published by the Irish American Cultural Institute}

- circulation in more than 20 countries -

An interdisciplinary journal with articles on Irish art, folklore, history, literature, politics, etc.

Book reviews, notes and queries, special departments.

$$
\$ 10.00 \text { a year }
$$

EIRE-IRELAND, Box 5026,

College of St. Thomas, St. Paul, Minn. 55105

\section{THE NEW ZEALAND JOURNAL OF HISTORY Editor: KeITh Sinclair}

Recent and Forthcoming Articles:

Keith Sinclair The Lee-Sutch Syndrome.

Peter O'Connor Conscientious Objectors 1916-18.

Miles Fairburn New Zealand Society: an interpretation.

Judith Elphick What's Wrong with Emma? The Feminist Debate in Colonial Auckland.

P. H. Rousseau Structure and Event in Anthropology and History.

Annual subscription $\$ N Z 6.00$

Published twice yearly by the University of Auckland

Private Bag

AUCKLAND, NEW ZEALAND 


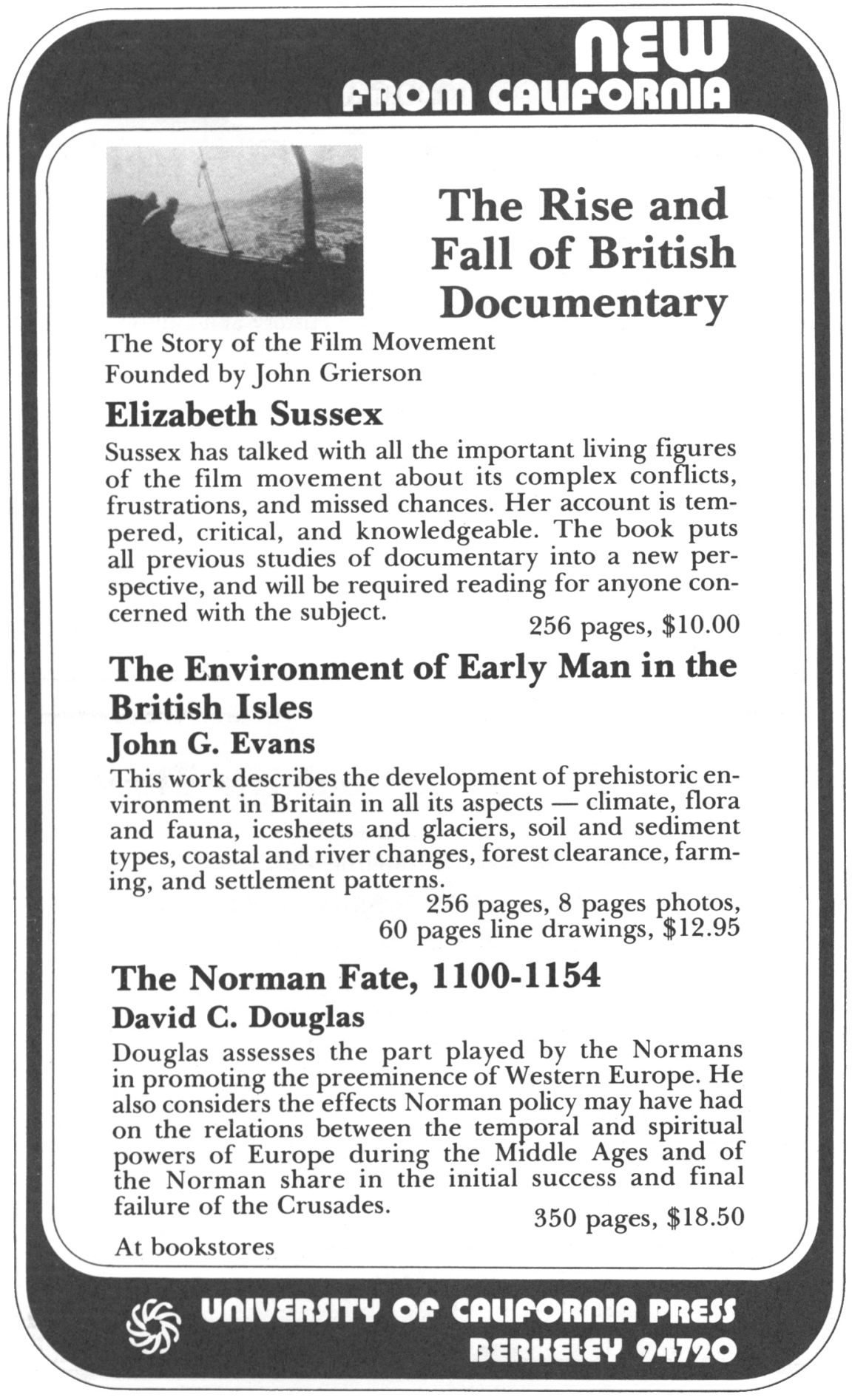




\section{The \\ William and Mary Quarterly}

A Magazine of Early American History

Published in January, April, July, and October

by the Institute of Early American History and Culture

Yearly subscription, $\$ 8.00$; student subscription, $\$ 5.00$, with student verification; Armed Forces subscription, $\$ 5.00$; single copies, Vols. I-XXVIII, \$1.50, Vol. XXIX and following $\$ 2.40$. Index to Vols. XVI-XXX (1959-1973), \$8.00. (Index orders payable to the Institute of Early American History and Culture); Index to Vols. I-XV (1944-1958) available from Kraus Reprint Corp.

All communications should be addressed to the Editor, The William and Mary Quarterly, Box 220, Williamsburg, Virginia 23185.

\section{Studies in Burke and His Time}

\section{A Journal Devoted to}

British, American, and Continental Culture, 1750-1800

\section{Published in Winter, Spring, and Fall}

By Texas Tech University

The editors invite essays on all aspects of late eighteenthcentury culture, including literature, history, music, fine arts, philosophy, and science.

Annual cost is $\$ 7.00$ and back issues are available. Subscriptions and other business correspondence should be addressed to Gift and Exchange Librarian, Texas Tech University Library, Lubbock, Texas 79409.

Editorial correspondence should be addressed to Jeffrey Smitten and Joel Weinsheimer, Editors, Studies in Burke and His Time, P.O. BOX 4530, Texas Tech University, Lubbock, Texas 79409. 


\section{THE JOURNAL OF BRITISH STUDIES TRINITY COLLEGE HARTFORD, CONNECTICUT}

The Journal of British Studies, founded in 1961, is published at Trinity College under the auspices of the Conference on British Studies. It was the result of the imaginative generosity of a Trinity alumnus, Frederick E. Hasler (Hon. LL.D. 1957) who contributed funds to the College for the specific purpose of establishing a learned periodical in the field of British history. Several Trinity alumni subsequently contributed to the fund and Trinity College now supports the publication of the Journal.

The Conference on British Studies is the official organization in the United States and Canada of scholars working in the field of British history and culture; its status as such is recognized by the American Historical Association of which it is an affiliate. Its nearly eight hundred members are drawn from fifty states and five provinces. It convenes twice each year, usually at New York University. The Conference awards a prize every five years for the best first book by an American or Canadian scholar.

The Conference sponsors a considerable publications program. It publishes the Journal of British Studies at Trinity College; the British Studies Intelligencer, a newsletter, at Western Washington State College, Bellingham, Washington; and Archives in British History and Culture, a series devoted to the publication of documents, at West Virginia University, Morgantown; and Current Research in British Studies, a quadrennial survey of research in progress in the United States and Canada, published at Kansas State University, Manhattan, Kansas and edited at Western Washington State College. The Conference also sponsors a series of short monographs, Studies in Britisb History and Culture, edited at Wittenberg University, Springfield, Ohio and published by the Shoe-String Press, Hamden, Connecticut. Under the aegis of the Conference, Cambridge University Press publishes a bibliographical and biographical series. Albion, including the proceedings of the Conference in its regional and national meetings, is published four times a year at Appalachian State University, Boone, North Carolina, and is sent to all members of the Conference.

In addition to the Conference on British Studies, there are several affiliates: the Pacific Coast Conference on British Studies, the Pacific Northwest Conference on British Studies, the Midwest Conference on British Studies, the Southern Conference on British Studies, and the New England Conference on British Studies. Each of these vital autonomous groups has its own officers, programs, and other activities. There are also local groups centered in Los Angeles, Detroit, Pittsburgh, and San Francisco.

The Journal of British Studies appears twice in the academic year, in the autumn and in the spring. The annual subscription is $\$ 8.00$. Checks for subscriptions and enquiries concerning advertising rates should be directed to the Business Manager, British Studies, Box 1315, Trinity College, Hartford, Connecticut, 06106.

Manuscripts should be sent, with self-addressed return stamped envelope, to the Editor, L. P. Curtis, Jr., Department of History, Brown University, Providence, Rhode Island, 02912. Articles should not exceed 8,000 words of text.

Volume XV, No. 2 will be published in the spring of 1976. 

